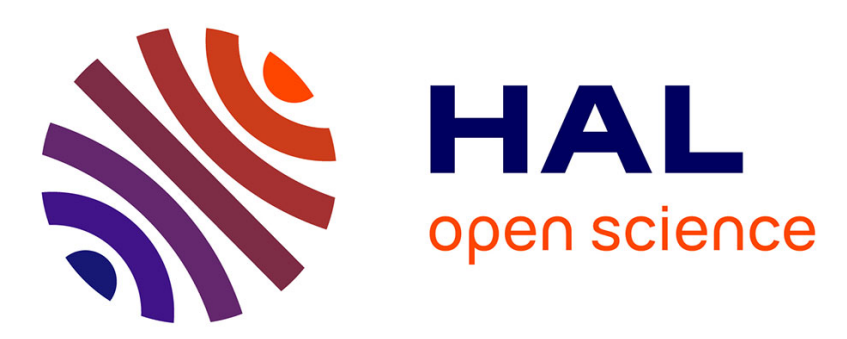

\title{
A Pragmatic Redefinition of Value(s): Toward a General Model of Valuation
}

\author{
Nathalie Heinich
}

\section{To cite this version:}

Nathalie Heinich. A Pragmatic Redefinition of Value(s): Toward a General Model of Valuation: Toward a General Model of Valuation. Theory, Culture and Society, 2020, 37, pp.75 - 94. 10.1177/0263276420915993 . hal-03221690

\section{HAL Id: hal-03221690 https://hal.science/hal-03221690}

Submitted on 11 May 2021

HAL is a multi-disciplinary open access archive for the deposit and dissemination of scientific research documents, whether they are published or not. The documents may come from teaching and research institutions in France or abroad, or from public or private research centers.
L'archive ouverte pluridisciplinaire HAL, est destinée au dépôt et à la diffusion de documents scientifiques de niveau recherche, publiés ou non, émanant des établissements d'enseignement et de recherche français ou étrangers, des laboratoires publics ou privés. 
A Pragmatic Redefinition of Value(s):

Toward a General Model of Valuation

\begin{abstract}
This paper is intended to draw the main theoretical lines of the notion of value, in order to avoid some flaws in the quantitative surveys on values as well as in some qualitative studies of value judgements. Through a number of redefinitions based on a pragmatic approach, inspired not only by Dewey's concept of "valuation" but also by the new French pragmatic sociology and by the pragmatist trend in linguistics, it tries to specify the conditions under which sociology can address the notion of "value" while avoiding their reduction to scholarly supports for morals or normative guides for action and evaluation. Meanwhile, it tries to construct a unified concept of value that would work for all the concerned disciplines: not only sociology but also economics, psychology, anthropology, and even philosophy.
\end{abstract}

\title{
Key words
}

Dewey - Pragmatism - Sociology of values -Valuation - Value

The issue of values is not new in sociology, but it has been addressed in often unsatisfactory ways: speculations without any anchoring in empirical investigation (Boudon, 1999; Demeulenaere, 1998; Kuty, 1998; Rezsohary, 2006); attempts to build up a normative "moral sociology" (Pharo, 2004); quantitative large surveys based on polls but without any clear definition of the term "value" (often confused with "attitudes", "preferences" or "beliefs") nor adapted observation protocols (Rokeach, 1973; Inglehart, 1977; Bréchon, 2000; Galland and Roudet, 2005; Schwartz, 2006), 
based on the implicit hypothesis that actors would be as aware of their principles of evaluation as of their behaviors and opinions (Heinich, 2010).

Historical investigation has no doubt produced remarkable contributions to the sociology of values (Weber, 1920; Kalberg, 2010). But values are most often reduced to the ethical (Forsé-Parodi, 2004) or to the economic dimension (Simmel, 1900; Boltanski-Esquerré, 2017), without considering the many other dimensions of the actors' axiological equipment (Heinich Schaeffer Talon-Hugon, 2014). Moreover, the long-standing confusion between values and norms has favored a focus on the latter, their production, their effects, their transgression. No doubt this focus on norms allowed fundamental sociological works (Elias, 1969; Goffman, 1956; Becker, 1963), but it does not fully address what makes norms effective, namely their grounding on relatively consensual axiological principles, which remain mostly under-investigated.

Besides, when qualitative methods have been applied to what may be framed as principles of judgment, the very word "value" has been avoided by their authors, in favor of concepts such as "worlds" or "orders of worth" (Boltanski and Thévenot, 1991), or "symbolic boundaries" (Lamont, 1992). Although major breakthroughs have been thus obtained, these proposals do not provide a sociological definition of the notion of value.

However, some specifically sociological investigations in the actors' relationship to values have happily emerged in the last generation, owing to the rise of pragmatic approaches. They come either from American philosophy (Dewey 1939; Bidet, Quéré, Truc 2011; Cefaï et alii 2015) or from post-Bourdieusian French sociology (Boltanski-Thévenot 1991; Latour 1989). They have implemented situated observations of the concrete processes of evaluation, justification or expertise (BessyChateauraynaud 1995; Dodier 1995; Lamont and Thévenot 2000; Lemieux 2000; Hennion and Fauquet 2000; Hennion 2004; Heinich 2009; Vatin 2012). Thus new and more qualitative methods of investigation have been experimented, borrowing either from field observation or from the systematic analysis of a body of controversies 
(Latour 1984; Heinich 1998; Chateauraynaud 2011; Berthoin-Antal, Hutter and Stark 2015; Chaumont 2017).

This paper is intended to draw the main theoretical lines sustaining the new pragmatic approaches of the issue of value: a definition which is most likely to become a redefinition. Under what conditions can sociology address the notion of "value" while remaining a social science rather than a scholarly support for morals or a normative guide for action and evaluation, as are moral philosophy and moral sociology? And under what conditions is it possible to construct a unified concept of "value" that would work for all the concerned disciplines - not only sociology but also economics, psychology, anthropology, philosophy? To answer these two questions I will replace a series of familiar but unsatisfactory oppositions by redefinitions deemed more appropriate to a pragmatic approach of its object.

Nine conceptual shifts will be proposed. Let us note them in stenographic form that will also serve as preview of the main arguments of the article: first, a shift from the notion of "value" to that of "valuation"; second, a shift from the opposition between value as intrinsic or extrinsic to the object, to a concept of value as a combination of mental frames, objective affordances and social institutions; third, a shift from two symmetrical misconceptions of value (as an essence or as an illusion) to its conception as a shared mental representation; fourth, a shift from the opposition between values and norms to an articulated set of mental representations and frames for action; fifth, a shift from the conception of value as a matter of price to an extended conception of value as a matter of measure, of attachment and of judgment; sixth, a shift from the opposition between values and interests to a distinction between public and private values; seventh, a shift from a conception of value focused on things to an extended conception also focused on persons, actions and states of the world; eighth, a shift from the opposition between "value" and "values" to an integrative model able to articulate the three meanings of the word "value" into a one and same research project; and ninth, a shift from the misleading 
opposition between interactionism and structuralism to a distinction between three articulated moments of valuation.

Such a redefinition of some basic issues in the sociology of values should open the way to a pluridisciplinary frame for an empirical and pragmatic study of the actual processes of valuation.

\section{To finish with value vs fact: shifting from value to valuation}

Entering the issue of value through evaluative acts is a fundamental condition of the pragmatic approach. It means passing from the value of an object to the close observation of the operations by which actors actually manifest the value they assign to this object (Brosch and Sander, 2016; Heinich 2017). It thus means focusing on acts (including this particular act called a "speech act" as studied by pragmatic linguistics: Austin, 1955; Goffman, 1981) and not only on mental representations. Those acts implement what John Dewey called a "valuation" (Dewey, 1939), that is, an attribution of value, which can be both positive (valorization) or negative (devalorization). In other words, value is obtained by action, in the process of qualification or requalification. This process has been introduced in the agenda of economic science by the French economic school called "économie des conventions", where the notion of "qualification" is central in the analysis (Eymard-Duvernay \& Thévenot, 1983; Eymard-Duvernay, 1986; Callon, 2009). It implies that the actor, far from passively evaluating a given object, actively participates in its very definition: that is "exactly what Dewey was after as he used the word "valuation", against the dualist one of evaluation" (Hennion, 2015: 48). Here the new French economic school meets Dewey's pragmatist approach around the notion of "qualification", as a possible equivalent of "valuation" (Trébuchet-Breitwiller, 2015: 171-172). In such a reversed perspective, value is no longer intrinsic to an object, and it is no longer the cause of the various forms of value attribution: rather it becomes the result of these valuations. Hence the phenomenological reversal, according to which value is not given but created. As French phenomenologist Raymond Polin has affirmed, "What 
characterizes value is never to be a given, but to be constantly reinvented, continuously recreated, or better, to be invention and creation in progress, conscious transcendence in the process of self-reflection and enactment" (Polin, 1944, 1952: 72).

However, one should also avoid the phenomenological inclination toward solipsism (everyone for oneself) and individualism (no institutions, no external constraint, no stabilization process): on the contrary, value is not created ex nihilo, but reconfigured and tested out of existing corpuses; and it is not produced by the free play of individuals, but is strongly constrained by institutions and regulations, that is to say by cognitive, legal, administrative, relational frameworks. It means that it does not pertain only to psychology, contrary to what German philosopher Heinrich Rickert suggested when proposing the submission of the ontology of value to the valuation act (Rickert, 2007: 63-64).

Refilling analysis with the collective, the institutional, the structural dimensions allows us to go up from value to valuation, while avoiding what Norbert Elias dismissed as the illusion of the homo clausus: the human being closed on him- or herself, defined independently of any relation or exogenous determination (Elias, 1970). It then becomes possible to elaborate a sociology of values that accounts for the complexity of the valuations actually produced by actors.

Contrary to a purely mentalistic approach, the study of valuations should be based on the description of the situations in which judgments actually take place within the space of axiological possibilities, that is the system of appreciation (for oneself) and of expression (for others) of value. This is why Dewey's perspective is a necessary starting point, but does not provide the whole set of methodological tools allowing a genuine sociological approach of values : that is, not only pragmatic but also empirically grounded rather than speculative.

Indeed the sociology of valuation should take into account not only the subject and the object of any valuating process, but also its actual context. The very situation in which a valuation occurs (from private talk to public statements or professional expertise) has to be considered on the same level and with the same attention as the 
actors' capacities and the object's properties (Heinich, 2017). But here, our model might borrow less to Dewey's pragmatism than to linguistic pragmatism, since the latter has provided actual investigations in the production of speech acts within their context, considered as being part of the very speech process (Bourdieu and Boltanski, 1975 ; Horn and Ward, 2005).

Another important claim for a pragmatic sociology of valuation is that it has to remain free of any kind of normative perspective, according to Weber's Wertfreiheit (Weber, 1919). This of course is a normative claim, but on the epistemic level of scholars' methods and concepts, and not on the ordinary level of actors' conceptions and opinions to which Weber referred (the confusion between both levels being one of the major obstacles to a full understanding of Weber's call for neutrality in the social sciences: Heinich, 2017). In other words, the sociology of valuation has nothing to do with helping actors in resolving conflicts, providing clues for good judgements, or fostering democratic ways of making decisions. The purpose of the sociology of valuation that we advocate here should remain a purely epistemic one, aiming not at making valuations acceptable but at discovering and analyzing how actors decide whether a valuation is acceptable or not. Here lies a basic rupture between a normative (or even political) position, and an analytico-descriptive (or scientific) one: the latter has nothing to do with critical social theory.

Nonetheless, both share a common effort to escape the traditional subject/object dualism: hence our second redefinition of value.

\section{To finish with value as either intrinsic or extrinsic: value as the product of objective} affordances, mental representations and social relations and institutions

Is value intrinsic or extrinsic to the valuated object? The former option has been favored by classical economics, according to which "things have an objective value, independent of market interactions", as French economist André Orléan (opponent to this paradigm) summarizes (Orléan, 2011: 107). According to his analysis, this intrinsic value can take various forms: the value of work, through the 
amount of work necessary for the production of an object, as with Adam Smith and Karl Marx; the value of rarity, as with Léon Walras; or the value of utility, as with neoclassical theory.

Against this traditional conception of an intrinsic value expressed by a price, a new school, trained in sociology and anthropology, takes into account the presence of a third entity in the attribution of a value to an object: be it the "mimetic desire" highlighted by René Girard (Girard, 1961); or the "conspicuous consumption aiming at a quest for prestige", as analyzed by Thornstein Veblen in his Theory of the Leisure Class (Veblen, 1899) ; or, later, Pierre Bourdieu's “distinction” (Bourdieu, 1979). In all these cases, value is externalized, since it no longer resides in the intrinsic properties of an object but in the price attributed to it through exchanges. Opposite to the substantialist conception proper to both common sense and classical and neoclassical economics, such a perspective eliminates the hypothesis of a fair price and, instead, focuses on monetary movements (Orléan, 2011: 227). This is a radical break with "substantial approaches to value, thought of as objective data, already there, intrinsic to goods" (Orléan, 2011: 185). Thus, value is no longer a substance but an institution, that is, a monetary institution, which founds the market economy: "Value is not in objects; it is a collective production that allows life in common. It has the nature of an institution" (Orléan, 2011: 328).

Although iconoclastic in the eyes of many economists, this conception is in line with well-established positions in sociology, anthropology and even aesthetics, advocating an extrinsic conception of value, detached from the valuated object and attached to the relationships to the object. Then intrinsic "value" becomes extrinsic "values", conceived as principles governing valuation.

Anthropologists too have shifted from an intrinsic to an extrinsic conception of value, in that it is constructed by relationships, and by relationships not only to valuated things but also to other humans. Indeed, the question faced by economists regarding the variability of prices allocated to a thing in one society is also faced by anthropologists regarding the variability of the value assigned to things in various 
cultures: the social bounds framing the transformations of value have been addressed by anthropologists such as - among others - Marilyn Strathern, Nancy Munn, David Graeber, Fred Myers or Arjun Appadurai (Arizpe 2008; Warnier 2008). For the latter in particular, the formation of value no longer resides in work or utility, but in the desire generated by an object according to the beings and to the situations it meets, so that its value essentially comes out of the "biography" of objects, the "social life of things" (Appadurai, 1988). So, whether in economics, sociology or anthropology, contemporary thought tends to shift from an intrinsic to an extrinsic conception of value.

But, as often when one has to choose between two logically incompatible options, a third position is possible, based not anymore on a dichotomy but on a continuous move from an extrinsic to an intrinsic polarity. One can indeed consider that the value of an object is based on several categories of resources, both extrinsic and intrinsic. At one end, as extrinsic resources, there are the perceptive patterns and evaluative categories available to valuators, in other words their mental representations; the relations between subjects and objects and between subjects and subjects; and the institutions that stabilize, objectify, and generalize valuation processes. At the opposite end, as intrinsic resources, there are the objective properties, in other words the "affordances" that an object offers to perception and evaluation (Gibson, 1979; Bessy and Chateauraynaud, 1995). And it is in the matching of these objective (or "objectal") properties, of these axiological dispositions, of these expectations and of these institutional frameworks that value is produced throughout valuation processes.

By the way, the notion of "affordance" obliges to take into account the material constraints to which any valuation is confronted, thus dismissing the postmodern illusion according to which the elements entering a judgement might change in the process. What might change is the way an object is "qualified", categorized, defined - in other words, the way it is mentally represented and actually treated but in no way its physical characteristics. This is another reason why the pragmatic 
sociologist should take distances from present time uses of philosophical pragmatism, often flirting with the idealistic belief in an infinite lability of the world we live in.

Meanwhile, introducing this notion of mental representation in the redefinition of value also allows us to escape some other dualist oppositions, as we shall see now.

\section{To finish with fact vs illusion: value as a shared mental representation}

The alternative between intrinsic and extrinsic value can be reframed into a series of homologous oppositions: objectivity vs subjectivity, necessity vs contingency, universality vs relativity, or fact vs illusion. The first term always refers to the metaphysical tradition, while the second refers to modern constructivism.

The latter has found a most successful trend in Bourdieu's critical sociology. There, the reduction of "facts" to mental categories, or representations, easily takes the form of their dismissal as "illusions", according to Heinich's comments on Bourdieu's thought (Heinich, 2007). In that perspective, values tend to be denounced as "myths": for example, when school fails to fully implement the ideal of equality, the latter is dismissed as an illusion, a myth imposed by "dominants" in order to better establish the "social reproduction" of inequalities (Bourdieu and Passeron, 1970). But when "social construction" is framed as "illusion", no place is left for the collective, interactional and argumentative dimensions of human experience. In particular the very notion of axiological representations, of values, is excluded.

The sociological opposition between value as a fact and value as a "social construction" reduced to an illusion echoes the philosophical opposition between objectivism and subjectivism. It has been aptly summed up by French aesthetician Gérard Genette: “The aesthetic subject loves an object because it is beautiful (objectivist theory), or the aesthetic subject judges an object beautiful because he loves it (subjectivist theory)." (Genette, 1997: 110). He offers an elegant solution to this alternative: the aesthetic valuation is indeed "subjectively objectivist", and at the 
same time "objectively subjectivist", in that the valuating subject must believe in the universality of the value he defends, as a principle, even if he is aware of its relativity, as a fact.

Another flaw of critical sociology consists in reducing values to their contextual anchorages, thus invalidating them by lack of universality: for example, the value of equality would appear "only" in present-day Western society, and therefore could not legitimately be called a "real" value. But such a critical relativism ignores the point that all values are contextual - as are all forms of human experience. The observation of actual practices evidences the plurality (in space) and the variability (in time) of axiological worlds: what Max Weber called the "war of gods", in other words the problem of the commensurability of values when confronting different valuation principles (Weber, 1922).

But the contextual and representational nature of values is not an obstacle to their claim to be shared aims in the society we live in. "Common life", as French philosopher Tzvetan Todorov explained (Todorov, 1995), is made not only of material things and of social institutions, but also of more or less shared representations (which are not necessarily "fictions", as critical thought tends to put it). Among them, axiological representations - that is, values - are not the least widely spread nor the least capable of agency. Thus, whereas the price of an object is a fact (quantified, variable, and "refutable" in the Popperian sense), its value is a representation (qualitative, variable, and questionable) - in other words, a more or less shared conception of what this object is worth.

Considering values not anymore as facts to be evidenced, nor as illusions to be dismissed, but as collective mental representations to be observed, described, explicated, analyzed: this means that actors' representations should be the object of the sociological insight, devoid of any criticism. Far from sustaining a fact vs value dichotomy, a neutral study of valuations actually deconstructs it by considering axiological representations (i.e. values) as social facts. 
Meanwhile, taking mental representations seriously also means that values (as axiological representations) should be distinguished from norms (as frames for action), even if the former are often implicit while the latter are usually easier to make explicit.

\section{To finish with values vs norms: articulating mental representations with frames for action}

Indeed, another reason why sociologists sometimes ignore or minimize the issue of value as a research object resides in a tendency to reduce it to the issue of norms. For example, the value of beauty disappears behind the norms of production of beautiful works in the eyes of artists, or the norms of appreciation of art works in the eyes of an audience (Amadieu, 2002). But this is a mistake, since norms are but the application of values to rules as prescriptions for action. Now, according to what principles of judgment are these norms implemented? This question hardly finds clear answers in the sociological study of norms, as there is no empirical inquiry that could provide any insight.

A norm is a prescription, an imperative for action, sustained by a value that can justify it (Livet, 2002: 145). The conformity to norms, as practical guides to match value principles to actions, makes it possible to attribute a value: thus conformity to moral norms is what we call virtue, while non-conformity is vice. Hence the strong connection of norms to actions, whereas values pertain not so much to behavior as to representations, or, in French philosopher Pascal Engel's words, "a certain sensitivity" (Engel and Mulligan, 2003: 8; Engel 2012: 145). Hence, too, the much more visibly social dimension of norms, because they are more action-oriented and more context-dependent - which makes them more accessible to sociology than values.

So values and norms should not be confused: the latter are very visible, the former are often implicit - which does not mean that they do not exist. They become explicit in cases of controversies, of normative tensions, of conflicts. In this perspective, the hypothesis put forward by Luc Boltanski and Arnaud Esquerre, 
according to which actors address values only when they disagree or doubt a price (Boltanski and Esquerre, 2016), describes but a special case of this relationship between norms and the values which sustain them: the case in which values become explicit.

However there is another way to underestimate or even dismiss the epistemic importance of the issue of value: it consists in reducing it to the issue of price. Let us see what it means, and how such a shortcoming can be avoided.

\section{To finish with the opposition between price and value: measure, attachment, judgment}

Another familiar opposition which obstructs a full understanding of the meaning of value is the one between price and value. In a pragmatic perspective, a sociology of values should focus on the actual forms under which valuation occurs: that is, first, measure (including, of course, price), second, attachment, and third, judgment. Our purpose is not to plead for judgment rather than measurement, or for measurement rather than attachment, or for attachment rather than judgment, since these three modalities may be at stake depending on the subjects, the objects and the contexts of valuation. They only need to be identified, described and analyzed, in order to understand what they mean for the actors, what they require and what they bring.

The measurement of value requires various instruments: codes (stars accompanying film reviews), awards (Palme d'or, literary prizes...), or numbers, in order to rate wines (the Robert Parker system), academic citations (the Eugene Garfield's Science Citation Index), or art works (the Willi Bongard's Kunst Kompass). In economic activity, the quantified measure is called "price", which for most economists means value ${ }^{i}$. But the reduction of valuation to quantified measurement and, more particularly, to price, often raises problems. Common sense tends to oppose the qualitative and supposedly intrinsic dimension of value to the quantitative and extrinsic dimension of price; art lovers regularly deplore the mismatch between price and the "true value" of art works; and sociologists 
stigmatize the discrepancy between the complexity of the actual processes of value attribution and the simplification required by any pricing: some would like to extend value beyond price (Ogien, 2016: 29) while others, on the contrary, consider that speaking of "value" only means criticizing or justifying a price when it comes to be contested, as we have already seen (Boltanski and Esquerre, 2016).

As for the second kind of value attribution - attachment - this mostly involves gestures or attitudes, which are more a matter of psychology (or even physiology in the case of emotional manifestations such as tears, crying out, clinging...). This means that unlike explicit quantified measurements and verbal judgments, attachment may remain implicit, or indirectly expressed through behaviors or narratives ("I have seen this film at least ten times!"). Already present in Dewey's approach (Dewey, 1939), this notion of attachment was introduced by pragmatists into French sociology in the 1990s, when insisting on the relationship to familiar objects (Thévenot, 2006), the role of objects in the circulation of networks (Latour, 2000), or the various modalities of "taste" (Hennion, 2004). Anthropology also takes hold of it (Dassié, 2010; Bonnot, 2014), as does psychoanalysis through a new attention to relations no longer between persons but between persons and objects (Tisseron, 2016) ${ }^{\mathrm{ii}}$.

The third and final form of valuation - judgment - is mostly a matter of words, ranging from mere common sense opinions to expert evaluations. Entering the issue of valuation through judgments or opinions is a fundamental condition of the pragmatic approach, since it means shifting from investigating the "value" of any object to observing the actual operations through which a value is attributed by an actor to an object. Once more, it thus also means focusing on speech acts rather than speculating on mental representations.

Actors' values are only accessible through the observation of their concrete activations in numerical, gestural or verbal expressions. An empirical and descriptive (rather than speculative and normative) sociology of values cannot therefore remain purely mentalist, exactly as indicated by pragmatic philosophy when differenciating between "appraisal" and "appreciation" (Dewey, 1939). 
Besides reducing values to norms and value to price, there is still another way to underestimate or misunderstand the issue of value in the social sciences: it consists in opposing "values" to "interests", as we shall see now.

\section{To finish with values vs interests: public values vs private values}

Are values autonomous entities and authentic motivations, or are they merely the translation or concealment of interests? The second term of this alternative implies a critical approach to the notion of values, eventually leading to its dismissal. This is, in fact, what is proposed by materialist and post-Marxist (in its Bourdieuian form) determinism, as well as by utilitarian determinism, which reduces any motivation to the defense of individual interests. In contemporary sociology, the critical paradigm, which has become particularly powerful, considers the actors' representations not as a reality to be analyzed but, rather, as an illusion to be unveiled, or as an ideology to be denounced, as we have seen before. Hence the discrediting of the notion of values, whatever they may be, as a "belief" having no other function than to hide interests (Heinich, 2007).

Bourdieu's sociology today embodies this critical approach, which a priori denies actors any motivation other than the perpetuation of domination, in its socalled "symbolic" form rather than in its material form, as with Marx. Let us take an example in the scientific world: in Bourdieu's view, the "ideal of disinterestedness" proper to the ethics of science is - as any form of gift - no more than a cover for the search for recognition (Honneth, 1992; Todorov, 1995), renamed "symbolic capital" in order to avoid any reference to psycho-affective needs or any ideal of justice (Bourdieu, 2001). In this perspective, anyone pretending to study the values at stake in the scientific world, by trying to explicate their logic and display their effects on the practices and conceptions of scientists' work, will necessarily be suspected of being naively deluded or, worse, complicit in a hidden search for personal profit.

This reduction of values to effective behavior makes it impossible to conceive that actors can live on two levels at the same time: in pursuit of private interests 
while respecting general values. But why assume that selfish interest would be more "true" than respect for values? Their logical incompatibility does not prevent them from being co-present in the actors' experience: scientists may well desire and seek recognition for their work while sincerely aiming for the disinterest and universality of science. Besides, the sociological tradition offers a famous example of taking the issue of values seriously, with one of the founding authors of the discipline, Max Weber. The very title of his most famous work, The Protestant Ethic and the Spirit of Capitalism (Weber, 1904) indicates his choice to give the axiological dimension a determining role in social and economic phenomena, by showing how the constitutive values of Protestantism (and, in particular, work, conceived as a "moral" activity: Vatin, 2008: 23) foster capitalist development (Kalberg, 2010).

Moreover, by broadening the notion of interest beyond the material interests put forward by the materialist theory, beyond the "symbolic" interests put forward by the Bourdieuian sociology of domination, and beyond the individual interests put forward by utilitarianism, it becomes easy to understand that attachment to common values can support identity interests (see the role of moral values as a cement for belonging: Collins, 1992: 28-29), which are probably as powerful as capitalistic accumulation, hierarchical positioning and hedonism. It is therefore unnecessary to disregard values in order to give weight to interests: not only are they both compatible, they probably often converge.

Meanwhile, not all values stand on the same level regarding their ability to be justified. The so-called "moral values" allow public expressions better than the socalled "interests", reduced to confidentiality in the private sphere or to denunciation in the public sphere. This is why the opposition between values and interests should rather be framed as a distinction between values that can be expressed publicly and those that can only be invoked or justified in private. "Public values" can be publicly claimed as reference values, whereas "private values" (analogous to Weber's "instrumental values") effectively guide actions, but can hardly be publicly claimed because of their lack of consistency with public values. The more or less private or 
public nature of a value naturally varies according to the context and, in particular, the field of activity: for example, beauty is a good example of private value, at least when applied to a person rather than to an object. This value is intensely used by people to classify and evaluate their contemporaries (and especially women), while it can hardly be publicly claimed as a valuation criterion, especially regarding professional recruitment (except for some representational occupations such as hostess). Because it is both a superficial and fundamentally unequal resource, it is doubly problematic, as shown by the systematic concealment or disqualification of cosmetic surgery (Amadieu 2002). It is nonetheless deeply invested in by a number of people, which makes it a genuine "private value", hardly reducible to a mere "interest".

It is well known that the issue of "interest" is a basic one in economy. In our view, it should not be abandoned but reframed as a private value, while the economic dimension of human motives should be reintegrated inside a more general model, including other social and human sciences.

7. To finish with the split between economics, psychology, sociology and philosophy: the four objects and the three dimensions of valuation

Things, people, actions, states of the world: these are the four categories of objects to which measures, attachments and judgments apply in a valuation process. It is all the more important to distinguish between these four objects of valuation because they are often ignored or underestimated: economic science, by focusing on price, implicitly reduces the issue of value to the value of things, as noticed by French philosopher Célestin Bouglé (Bouglé, 1922); moral philosophy, by focusing on ethics, tends to reduce it to the value of people (Bouglé, 1922: 63); sociology, by focusing on norms, tends to reduce it to the value of actions (Boltanski and Thévenot, 1991; Graeber, 2001); and political science, by focusing on policies, tends to reduce it to the value of the states of the world. None of these four focuses are wrong, but they are 
partial: understanding what an axiological competence is made of implies taking into account all the possibilities it is likely to mobilize.

Besides, we have seen that axiological representations, in other words "values", depend, first, on the material properties of the object of judgment, through its affordances; second, on the actors' axiological competences (valuation criteria and principles); and third, on the actual contexts (be they micro or macro) in which the interaction between objects and subjects occurs. Subject, object, context: it is in the interplay of these three operators that value is produced through the whole set of operations by which a quality is assigned to an object. Hence, the role of pragmatic sociology, attentive to "situated action", in highlighting the axiological level under the normative level (Glaser and Strauss 1967).

When the three forms (measure, attachment, judgment), the four objects (things, persons, actions, states of the world) and the three moments (object, subject, context) of valuation are integrated in a common process, rather than considered separately, borders between disciplines tend to weaken, in favor of a unique model inside which the various disciplines may position their own perspective, without challenging the other ones. The pragmatic study of valuation becomes a distributed process for social sciences, instead of a competitive or hegemonic attempt to foster one discipline against the others.

Another consequence of such a global approach is that, by relativizing the economic approach, it allows to articulate "value" with "values". But this means that we should distinguish between three meanings of the word "value".

\section{To finish with the opposition between value and values}

Long ago, Talcott Parsons proposed a pact to his colleagues in the Harvard Economics Department: “You economists study value; we sociologists study values. You will refer to economy; we will refer to the social relationships in which economic phenomena are embedded" (Kluckhohn, 1951; Stark, 2009: 16). Indeed, this kind of split 
between disciplines is precisely what should be avoided, with the help of a clear distinction between the several meanings commonly attributed to the word "value".

In its first and most common meaning, "value" refers to the worth, importance, quality of an object (thing, person, action, state of the world) - whether or not it is accessible to pricing (measuring) rather than to attachment or judgment. Once endowed with "value", things become "values" in the second sense of the term, that is concrete goods, commodities; people become worthy human beings, possessing virtues such as cheerfulness, honesty, courage, or possessing markers of excellence such as luxury goods and leisure (Veblen, 1899), or distinctive economic, cultural or social "capital" (Bourdieu, 1979); actions (be it a smile, a rescue act or a bullfight performance) become fair actions because they conform to standards; and states of the world (from climate to peace or democracy) also become goods, but abstract rather than material: this is the second meaning of "value", conceived as something endowed with any kind of "value", and thus having become a "good" (at least in the case of a thing).

The third meaning of "value" is different: it refers to the abstract principles according to which "value" (in the first meaning) is bestowed upon an object, thus transformed into a "value" (in the second meaning). These principles are quite familiar: for example, the beauty of a thing, the intelligence of a person, the courage of an action, the coherence of a state of the world. Beauty, intelligence, courage, coherence are all "values" in the sense that they make valuation possible. They appear in value judgments, especially in case of controversies, which thus provide rich material for an empirical analysis of the actors' relationship to value.

Considering this threefold dimension of "value", it becomes possible to build up a research program focusing on the way values-as-principles (third meaning) are applied to objects in order to endow them with value-as-worth (first meaning), allowing them to become (in a more or less consensual and stable way) a value-asgood (second meaning). This is where an interdisciplinary program can start, including the economic approach to value-as-worth and to values-as-goods, as well 
as the linguistic study of value judgments, the psychological observation of attachments, and the sociological, historical and anthropological insights to value-asprinciple, part of a shared repertoire of values which constitute what could be called an "axiological grammar".

No need, therefore, to distinguish between "value" and "values": they are but different moments of a process of valuation to be observed, described, explicated, and even explained.

This is why a valuation process needs to be described according to its various moments, which themselves refer to various theoretical frames. It thus becomes possible to articulate them in spite of opposing them as competing theories.

\section{To finish with the opposition between interactionism and structuralism: the three moments} of evaluation

The multiple dimension of axiological experience also concerns its temporality and, correlatively, the status of the theoretical tools likely to reflect it. Indeed, values are present three times in the course of a valuation. First, they exist before the situation, as part of a repertoire of representations shared by actors within the same culture, transmitted by education and incorporated into their habitus: this is the structural, deterministic dimension of experience, analogous to the grammar practiced by the speakers of a language, or to those "frames" highlighted by Erving Goffman (Goffman 1974), which implicitly structure and predetermine the way in which we perceive and treat reality. By focusing on "competence" rather than on "performance", the inductive uncovering of the underlying axiological system (the "grammar") which organizes the actor's relationship to values perfectly fits the framework of structuralism ${ }^{1}$.

\footnotetext{
${ }^{1}$ The concept of « grammar » has been introduced in current French sociology through the "pragmatic" trend partly initiated by Luc Boltanski and Laurent Thévenot (1991); for a conceptual development of what "grammar" means in sociology, see also Lemieux, 2009.
} 
Second, values also develop during the valuation situation, by applying concretely to a given object, with various degrees of effectiveness. This is the interactionist dimension of sociological inquiry, focusing on the concreteness of actions in their contexts, as well as on the wide variety of resources available to actors in order to negotiate, especially in conflictual situations. Here is the perfect place for the interactionist tradition in sociology, though it is theoretically the opposite of the structuralist tradition.

Thirdly and finally, values are implemented after the situation of valuation, due to testing them through objects and within contexts: they can be modulated, refined, affirmed or, on the contrary, weakened or outdated, leading to a permanent re-elaboration of the repertoire available to actors - exactly as with language. This is the constructivist dimension of the sociological program, which leaves room for historical evolution, for actors' inventive capacities, and for a consequential perspective on the actual effects of valuations.

No particular theoretical approach should, therefore, be a priori imposed: the relevance of each depends on the moment of the valuation experience which is at stake. Rather than indulging in sterile clan struggles between supporters of one or another theoretical program, we'd rather concentrate on the way actors move between the three moments of valuation - before, during and after the valuation situation - as well as between its three dimensions - objectal, representational and contextual. Thus, shifting from an essentialist conception of value(s) to a contextualization of valuation acts, we let a new field open for the study of the various qualifications of experience.

\section{Conclusion}

Value is thus the result of the whole set of operations by which a quality is assigned to an object, with varying degrees of consensus and stability. These operations depend on the nature of the valuated object, on the nature of the valuating subjects, and on the nature of the valuation context. In other words, value 
is neither objective, nor subjective, nor arbitrary: it is triply motivated by the affordances that an object offers to valuation, by the collective representations undertaken by actors, and by the possibilities offered by the contexts in which these representations are activated regarding an object. This is how a properly sociological definition of "value" in the first sense (worth) can be constructed, which makes it possible to empirically study its manifestations when implementing "values" in the third sense (value principles), thus creating "values" in the second sense (goods).

Beyond the normativity of moral philosophy and moral sociology; beyond the lack of a theoretical definition of "values" in the said "sociology of values"; beyond the reduction of values to "morals" or to norms, and of valuation to "justification": it now becomes possible to build up an empirical inquiry into actual processes of valuation. This pragmatic shift from a sociology of values to a sociology of valuation makes it possible to consolidate the orientation of our disciplines towards a valuefree orientation, aiming not at praising nor criticizing, but at understanding and explaining the actors' relationship to axiological principles, their contextual activation and their justification. 


\section{*REFERENCES}

Amadieu, Jean-François (2002) Le Poids des apparences. Beauté, amour et gloire. Paris : Odile Jacob.

Appadurai, Arjun (1988) The Social Life of Things. Commodities in Cultural Perspective. Cambridge: Cambridge University Press.

Arizpe, Lourdes (2008) The Ritual and the Promise. Why People Value Social Ritual. In: Hutter, Michael and Throsby, David (eds) Beyond Price. Value in Culture, Economics and the Arts. Cambridge: Cambridge University Press.

Austin, John (1955) How to do Things with Words. Oxford: Clarendon Press.

Becker, Howard (1963) Outsiders. Glencoe: The Free Press.

Berthoin-Antal, Ariane, Hutter, Michael, Stark, David, eds (2015) Moments of Valuation. Exploring Sites of Dissonance. Oxford : Oxford University Press.

Bessy, Christian, Chateauraynaud, Francis (1995) Experts et faussaires. Pour une sociologie de la perception. Paris : Métailié.

Bidet, Alexandra, Quéré, Louis, Truc, Jérôme (2011) « Ce à quoi nous tenons. Dewey et la formation des valeurs ", introduction à Dewey, John, La Formation des valeurs. Paris, La Découverte.

Boltanski, Luc, Thevenot, Laurent (1991) De la justification. Les économies de la grandeur. Paris : Gallimard. 
Boltanski, Luc, Esquerré, Arnaud (2017) L'énigmatique réalité des prix. Sociologie, $7(1)$.

Bonnot, Thierry (2014) L'Attachement aux choses. Paris : éditions du CNRS.

Boudon, Raymond (1999) Le Sens des valeurs. Paris : PUF.

Bouglẻ, Célestin (1922) Leçons de sociologie sur l'évolution des valeurs. Paris : Armand Colin.

Bourdieu, Pierre, Passeron, Jean-Claude (1970) La Reproduction. Eléments pour une théorie du système d'enseignement. Paris : éditions de Minuit.

Bourdieu, Pierre, Boltanski, Luc (1975) «Le fétichisme de la langue et l'illusion du communisme linguistique ». Actes de la recherche en sciences sociales, vol. 1, n 4 .

Bourdieu, Pierre (1979) La Distinction. Critique sociale du jugement. Paris : éditions de Minuit.

Bourdieu, Pierre (2001) Science de la science et réflexivité. Paris : Raisons d'agir.

Brẻchon, Pierre (ed.) (2000) Les Valeurs des Français. Evolutions de 1980 à 2000. Paris: Armand Colin.

Brosch, Tobias, Sander, David (eds) (2016) From values to valuation. In : Handbook of Value. Oxford : Oxford University Press. 
Callon, Michel (2009) La formulation marchande des biens. In : Vatin, François (ed.)

Evaluer et valoriser. Une sociologie économique de la mesure. Toulouse : Presses

Universitaires du Mirail.

Cefaï, Daniel et alii (2015) « Introduction », special issue « Sociology of Valuation and Evaluation », Human Studies, 38, 1.

Chateauraynaud, Francis (2011) Argumenter dans un champ de forces. Essai de balistique sociologique. Paris : Pétra.

Chaumont, Jean-Michel (2017) Survivre à tout prix? Essai sur l'honneur, la résistance et le salut de nos âmes. Paris : La Découverte.

Collins, Randall (1992) Sociological Insight. An Introduction to Non-Obvious Sociology.

Oxford : Oxford University Press.

Dassié, Véronique (2010) Objets d'affection. Une ethnologie de l'intime. Paris : éditions du Comité des travaux historiques et scientifiques.

Demeulenaere, Pierre (1998) « La différence entre le relativisme des valeurs et la pluralité des valeurs du point de vue d'une sociologie de l'art ». in Mesure, Sylvie, La Rationalité des valeurs. Paris : PUF.

Dewey, John (1939) Theory of Valuation. International Encyclopedia of Unified Science, II(4): 1-67.

Dodier, Nicolas (1993) L'expertise médicale. Essai de sociologie sur l'exercice du jugement. Paris : Métailié. 
Elias, Norbert $(1969,1973)$ La Civilisation des mœurs. Paris : Calmann-Lévy.

Elias Norbert $(1970,1978)$ What is Sociology? London: Hutchinson.

Engel, Pascal \& Mulligan, Kevin (2003) Normes éthiques et normes cognitives. Cités, $3(15): 171-186$.

Engel, Pascal (2012) Les Lois de l'esprit. Julien Benda ou la raison. Paris : Ithaque.

Eymard-Duvernay, François, Thévenot, Laurent (1983) Les Investissements de forme: leurs usages pour la main d'œuvre, INSEE, $n^{\circ} 1878 / 432$.

Eymard-Duvernay, François (1986) La Qualification des produits. Le travail, marché, règles, conventions, Paris, INSEE-Economica : 239-247.

Forsé, Michel, Parodi, Maxime (2004) La Priorité du juste. Eléments pour une sociologie des choix moraux. Paris : PUF.

Galland, Olivier Roudet, Bernard (2005) Les Jeunes Européens et leurs valeurs. Europe occidentale, Europe centrale et orientale. Paris : La Découverte.

Genette, Gérard (1997) L'OEuvre de l'art. 2. La relation esthétique. Paris : éditions du Seuil.

Gibson, James Jerome (1979) The Ecological Approach to Visual Perception. Boston : Houghton Mifflin $\mathrm{C}^{\circ}$.

Girard, René $(1961,1978)$ Mensonge romantique, vérité romanesque. Paris : Livre de poche. 
Glaser, Barney Galland, Strauss, Anselm Leonard. (1967) The Discovery of Grounded Theory. Chicago: Aldine.

Goffman, Erving (1956) The Presentation of Everyday Life. New York: Doubleday.

Goffman, Erving (1974) Frame Analysis. An Essay on the Organization of Experience. New York: Harper and Row.

Goffman, Erving (1981) Forms of Talk. Philadelphia: University of Pennsylvania Press.

Graeber, David (2001) Toward an Anthropological Theory of Value; The False Coin of Our Own Dreams. New York: Palgrave.

Heinich, Nathalie (1998) L'Art contemporain exposé aux rejets. Études de cas. Paris : Jacqueline Chambon.

Heinich, Nathalie (2007) Pourquoi Bourdieu. Paris: Gallimard.

Heinich, Nathalie (2009) La Fabrique du patrimoine. De la cathédrale à la petite cuillère. Paris : éditions de la Maison des sciences de l'homme.

Heinich, Nathalie (2010) Note sur les méthodes quantitatives en sociologie des valeurs. Bulletin de méthodologie sociologique, 108: 5-13.

Heinich, Nathalie, Schaeffer, Jean-Marie, Talon-Hugon, Carole, eds. (2014), Par-delà le beau et le laid: les valeurs de l'art. Rennes : Presses universitaires de Rennes.

Heinich, Nathalie (2017) Des valeurs. Une approche sociologique. Paris : Gallimard. 
Hennion, Antoine (2004) Une sociologie des attachements. D’une sociologie de la culture à une pragmatique de l'amateur. Sociétés, 3(85): 9-24.

Hennion, Antoine (2015) Paying Attention : What is Tasting Wine about ? in Berthoin-Antal, Ariane, Hutter, Michael, Stark, David (eds) Moments of Valuation. Exploring Sites of Dissonance. Oxford: Oxford University Press.

Honneth, Axel $(1992,1995)$ The Struggle for Recognition. The Moral Grammar of Social Conflicts. New York : Polity Press.

Horn, Laurence \& Ward, Gregory (2005) The Handbook of Pragmatics. Oxford: Blackwell.

Inglehart, Ronald (1977) The Silent Revolution: Changing Values and Political Styles among Western Publics. Princeton: Princeton University Press.

Kalberg, Stephen (2010) Les Valeurs, les idées et les intérêts. Introduction à la sociologie de Max Weber. Paris: La Découverte.

Kluckhohn, Clyde (1951) Values and Value-orientations in the Theory of Action: an Exploration in Definition and Classification. In: Parsons, Talcott and Shils, Edward (eds.) Towards a General Theory of Action. Cambridge: Harvard University Press.

Kuty, Olgierd (1998) La Négociation des valeurs : introduction à la sociologie. Bruxelles : De Boeck.

Lamont, Michèle (1992) Money, Morals and Manners. The Culture of the French and American Upper-Middle Class. Chicago : University of Chicago Press. 
Lamont, Michèle, Thévenot, Laurent, eds. (2000) Rethinking Comparative Cultural

Sociology. Repertoires of Evaluation in France and the United States. Cambridge : Harvard University Press.

Latour, Bruno (1984) Les Microbes, guerre et paix. Paris, Métailié.

Latour, Bruno (1989) La Science en action. Paris : La Découverte.

Latour, Bruno (2000) Factures/fractures. De la notion de réseau à celle d'attachement. In : Micoud, André, Peroni, Michel (eds) Ce qui nous relie. La Tour d'Aigues : éditions de l'Aube.

Lemieux, Cyril (2000) Mauvaise presse. Une sociologie compréhensive du travail journalistique et de ses critiques. Paris : Métailié.

Lemieux, Cyril (2009) Le Devoir et la grâce. Paris : Economica.

Livet, Pierre (2002) Émotions et rationalité morale. Paris : PUF.

Ogien, Albert (2016) Qu'est-ce qui fait valeur dans notre société? In Bocquet, Bernard (ed.), La Fièvre de l'évaluation. Lille : Presses universitaires du Septentrion.

Orléan, André (2011) L'Empire de la valeur. Refonder l'économie. Paris : éditions du Seuil.

Pharo, Patrick (2004) Morale et sociologie. Paris : Gallimard-Folio.

Polin, Raymond $(1944,1952)$ La Création des valeurs. Paris : PUF. 
Rezsohazy, Rudolf (2006) Sociologie des valeurs. Paris : Armand Colin.

Rickert, Heinrich (2007) Le Système des valeurs. Paris: Vrin.

Rokeach, Milton (1973) The Nature of Human Values. New York: The Free Press.

Rokeach, Milton (1976) Beliefs, Attitudes, and Values: A Theory of Organization and Change. San Francisco : Jossey-Bass.

Schwartz, Shalom H. (2006) Les valeurs de base de la personne : théories, mesures et applications. Revue française de sociologie, 47(4) : 929-968.

Simmel, Georg (1900, 1987) Philosophie de l'argent. Paris : PUF.

Stark, David (2009) Assets of Ambiguity. Accounts of Worth in Economic Life. Princeton : Princeton University Press.

Thévenot, Laurent (2006) L'Action au pluriel. Sociologie des régimes d'engagement. Paris : La Découverte.

Tisseron, Serge (2016) Comment l'esprit vient aux objets. Paris : PUF.

Todorov, Tzvetan (1995) La Vie commune. Essai d'anthropologie générale. Paris : éditions du Seuil.

Trébuchet-Breitwiller, Anne-Sophie (2015) Making Things Precious: A Pragmatist Inquiry into the Valuation of Luxury Perfumes, in Berthoin-Antal, Ariane, Hutter, Michael, Stark, David (eds) Moments of Valuation. Exploring Sites of Dissonance.

Oxford: Oxford University Press. 
Vatin, François (2008). Le Travail et ses valeurs. Paris : Albin Michel.

Vatin, François, ed. (2012) Evaluer et valoriser. Une sociologie économique de la mesure.

Toulouse, Presses Universitaires du Mirail.

Veblen, Thornstein (1899) The Theory of the Leisure Class: An Economic Study of Institutions. New York: The Modern Library.

Warnier, Jean-Pierre (2008) Les politiques de la valeur. Revue européenne d'analyse des sociétés politiques, $4: 1-41$.

Weber, Max $(1904,1930)$ The Protestant Ethic and the Spirit of Capitalism. New York: Allen and Unwin.

Weber, Max $(1922,1978)$ Economy and Society. Berkeley: University of California Press.

Weber, Max $(1919,1959)$ Le Savant et le politique. Paris : Plon. 


\section{Biographical note}

Nathalie Heinich, a French sociologist, is senior researcher at the French National Center for Scientific Research (CNRS) and presently works within the Ecole des Hautes Etudes en Sciences Sociales (EHESS, Paris). Besides numerous articles in academic and cultural journals, she has published more than fourty books, dealing with the status of artist, the notion of author, contemporary art, the issue of identity, the history and epistemology of sociology and, more recently, values. Her books have been translated into fifteen languages, but only one into English (The Glory of Van Gogh, Princeton University Press 1996).

22 Place de la Nation 75012 Paris, France

\section{Heinich@ehess.fr}

\footnotetext{
' However some economists try to avoid this reduction of value to price by including in their analysis not only a quantification but also a qualification of goods: see Callon, 2009: 268).

ii Note that attachments might be the only base for a study of animals' relationship to valuation, through their expression of tastes and preferences.
} 